\title{
SURFACTANT-POLYMER FLOODING PERFORMANCE IN HETEROGENEOUS TWO-LAYERED POROUS MEDIA
}

\author{
M.T. Fathaddin ${ }^{1}$, Asri Nugrahanti ${ }^{1}$, Putri N. Buang ${ }^{2}$ \\ AND K.A. ELRAEIS ${ }^{2}$ \\ ${ }^{1}$ Department of Petroleum Engineering, Universitas Trisakti, Indonesia \\ ${ }^{2}$ Department of Geoscience and Petroleum Engineering, \\ Universiti Teknologi PETRONAS, Malaysia
}

\begin{abstract}
In this paper, simulation study was conducted to investigate the effect of spatial heterogeneity of multiple porosity fields on oil recovery, residual oil and microemulsion saturation. The generated porosity fields were applied into UTCHEM for simulating surfactant-polymer flooding in heterogeneous two-layered porous media. From the analysis, surfactant-polymer flooding was more sensitive than water flooding to the spatial distribution of multiple porosity fields. Residual oil saturation in upper and lower layers after water and polymer flooding was about the same with the reservoir heterogeneity. On the other hand, residual oil saturation in the two layers after surfactant-polymer flooding became more unequal as surfactant concentration increased. Surfactant-polymer flooding had higher oil recovery than water and polymer flooding within the range studied. The variation of oil recovery due to the reservoir heterogeneity was under $9.2 \%$.
\end{abstract}

ABSTRAK: Dalam makalah ini, kajian simulasi dijalankan untuk mengetahui kesan heterogeniti spasial berbagai-bagai medan porositi pada perolehan minyak, ketepuan minyak baki dan mikroemulsi. Medan-medan porositi yang dijana digunakan ke dalam UTCHEM untuk mensimulasi pembanjiran surfaktan-polimer di dalam media berpori berlapis-dua heterogen. Dari analisis, pembanjiran surfaktan-polimer lebih peka daripada pembanjiran air pada taburan spasial berbagai-bagai medan porositi. Ketepuan minyak baki di lapisan atas dan bawah selepas pembanjiran air dan polimer adalah hampir sama pada heterogeniti reserbor tersebut. Di sisi lain, ketepuan minyak baki dalam kedua lapisan selepas pembanjiran surfaktan-polimer menjadi lebih tak sama ketika kepekatan surfaktan ditingkatkan. Pembanjiran surfaktan-polimer mempunyai perolehan minyak yang lebih tinggi daripada pembanjiran air dan polimer dalam julat yang diteliti. Perbezaan perolehan minyak akibat heterogeniti reserbor di bawah $9.2 \%$.

KEY WORDS: Heterogeneity, Porosity, Surfactant-polymer flooding, Recovery factor

\section{INTRODUCTION}

The surfactant-polymer flooding is aimed to enhance oil recovery (EOR). The surfactant-polymer is injected into the reservoir as a finite slug. The slug is then pushed towards the producer by a water drive. Several interactions between surfactant and reservoir fluids occur due to the injection such as microemulsion phase creation, adsorption, wettability alteration, and interfacial tension (IFT) reduction [1, 2]. The 
surfactant helps in recovering the oil through oil solubilization and oil mobilization [3]. The former is the result of the microemulsion phase creation and adsorption, while the latter is the result of the wettability alteration and IFT reduction. The polymer solution has an elevated viscosity, which is useful to reduce the water mobility. Further water mobility reduction is caused by polymer retention and adsorption [4]. The reduction in water mobility improves the displacement conditions for increasing oil recovery. The displacement conditions which are improved cover viscous fingering reduction, fractional flow improvement, and the increase of area and vertical sweep efficiency [5, 6].

Additional recovery the after secondary recovery depends upon three factors: oil in place at the start of the flooding, reservoir sweep efficiency, and microscopic displacement efficiency. Reservoir sweep efficiency is the key factor in determining the final residual oil of water flooding within an economic limit [7]. The sweep efficiency is dependent upon the reservoir heterogeneity that affecting the flood front, breakthrough, and flow pattern of the injecting fluid.

The effects of reservoir heterogeneity in surfactant-polymer flooding have been reported. Dakhlia [8] investigated the effect of spatial heterogeneity of multiple permeability fields. It was found that water-flooding was less sensitive than surfactant flooding to the spatial distribution of heterogeneity. Shiyi et al. [9] studied the effects of vertical heterogeneity of multilayered reservoir models on chemical combination flooding. It was found that both water and chemical flooding deteriorated along with the increase of reservoir heterogeneity. However, comparing with water flooding, the EOR extent of chemical flooding increased with reservoir heterogeneity under its certain scope. Zhang et al. [10] performed stochastical analysis to measure the effect of soil spatial variability and heterogeneity on the recovery of denser-than-water non-aqueous phase liquids (DNAPL) by injecting a surfactant solution. It was found that the average DNAPL recovery decreased exponentially with increasing soil heterogeneity, characterized by the standard deviation of the log of permeability.

In this paper the effects of spatial heterogeneity of multiple porosity fields on surfactant-polymer, polymer flooding, and water flooding were studied. For this purpose, heterogeneous two-layered reservoir models were generated. Permeability of the two layers was set to be equal in order to focus on porosity parameter effect. The porosity values followed a normal distribution, while its spatial structure was described by a variogram.

\section{METHOD}

\subsection{Simulation Model}

UTCHEM is a three-dimensional, three-phase, compositional chemical flood simulator. The simulator was originally developed by Pope and Nelson [11]. The numerical model used for the surfactant-polymer flooding simulation is an extension of the model used in the simulator. The simulator takes into account the saturation of water, oil, and microemulsion. In this study, UTCHEM was applied to investigate the effect of spatial distribution of heterogeneity on oil recovery, oil and microemulsion saturation. 


\subsection{Simulation Setup}

The parameters of surfactant-polymer flooding simulation were taken from Dakhlia [8] and are listed in Table 1.

For each case, a quarter five-spot was initialized with initial water saturation. One injection well was located near the South-West corner of the $\mathrm{X}-\mathrm{Y}$ plane, with $\mathrm{X}$ and $\mathrm{Y}$ coordinates of $25 \mathrm{ft}$ and $25 \mathrm{ft}$. One production well was located near the North-East corner with $\mathrm{X}$ and $\mathrm{Y}$ coordinates of $475 \mathrm{ft}$ and $475 \mathrm{ft}$. All the wells are vertical, completed in the $\mathrm{Z}$ direction and connected to all layers. The boundaries were modeled as closed reservoir rock.

Table 1: Data used in the simulation.

\begin{tabular}{|l|c|}
\hline Property & Value \\
\hline The dimension of the porous media [ft x ft x ft] & $500 \times 500 \times 60$ \\
\hline Grid size & $10 \times 10 \times 2$ \\
\hline Horizontal permeability [md] & 50 \\
\hline Vertical permeability [md] & 5 \\
\hline Initial water saturation & 0.3 \\
\hline Average porosity & 0.2 \\
\hline Water viscosity [cp] & 0.75 \\
\hline Oil viscosity [cp] & 8 \\
\hline Specific weight of water [psi/ft] & 0.433 \\
\hline Specific weight of oil [psi/ft] & 0.388 \\
\hline Surfactant concentration in solution, $\mathrm{C}_{\mathrm{s}}[\%]$ & $0,1.25,2.5,5$ \\
\hline Polymer concentration in solution, $\mathrm{C}_{\mathrm{p}}[\%]$ & 0.1 \\
\hline
\end{tabular}

The simulations of surfactant-polymer flooding were carried out using 0.25 pore volume (PV) of surfactant-polymer solution and followed by $1 \mathrm{PV}$ of chase water. After that, all of the simulations with the same reservoirs were repeated for water flooding. In each simulation of water flooding, 1.25 PV water was injected. The results of surfactantpolymer flooding and water flooding simulations were then compared and analyzed.

\subsection{Random Fields of Rock Porosity}

The variogram is a measure of dissimilarity between two points in space separated by a distance $h$ [12]. The variogram is a geostatistical tool for modeling spatial variability [13]. Matheron [14] proposed a method of moments approach to approximate the variogram [15]:

$$
2 \gamma(h)=\frac{1}{N(h)} \sum_{i=1}^{N(h)}\left[z\left(u_{i}\right)-z\left(u_{i}+h\right)\right]^{2}
$$

where $\gamma$ is the variogram; $h$ is the separation vector; $N(h)$ is the number of pairs of data separated by vector $h$; $u$ is location and $z$ of random variable of a rock property. 
The mean of porosity was set equal to the porosity of the homogeneous rock $(0.20)$. Four values of standard deviation of porosity $(0.25,0.5,0.75$, and 1.0$)$ were selected to generate random fields of the rock porosity. The correlation lengths in the $X$ and $Y$ directions were the same as grid block size of $50 \mathrm{~m}$. For each simulation, two layers of random porosity fields were generated for $\mathrm{X}$ and $\mathrm{Y}$ directions independently. Porosity fields in the $\mathrm{Z}$ direction was then calculated according to the anisotropy ratios. For the same set of values of mean, variance, and correlation lengths, different porosity fields were generated by setting different seed values for the random number generator in the program. For each simulation, a generated porosity field was incorporated into UTCHEM to simulate surfactant-polymer or water flooding in a heterogeneous porous medium.

\section{RESULTS AND DISCUSSION}

For each of the four values of standard deviation of porosity, 10 randomly porosity fields were generated. Each of the random porosity fields was incorporated with UTCHEM for simulations of surfactant flooding in heterogeneous two-layered porous media. The simulated results were then used to analyze the effects of reservoir rock variability on the distribution and recovery of oil and microemulsion saturations.

Figure 1 shows oil saturation ratio between the first and the second layers after injecting 1.25 pore volumes (PV) of surfactant-polymer solution and chase water. The figure indicates that the residual oil saturation ratio for surfactant-polymer flooding $\left(\mathrm{C}_{\mathrm{s}}>\right.$ $0 \%)$ fluctuate more than water flooding $\left(\mathrm{C}_{\mathrm{s}}=0 \%, \mathrm{C}_{\mathrm{p}}=0 \%\right)$ to the spatial distribution of multiple porosity fields. Further results presented in Fig. 1 indicate that residual oil saturation ratio of polymer flooding $\left(\mathrm{C}_{\mathrm{s}}=0 \%, \mathrm{C}_{\mathrm{p}}=10 \%\right)$ was closer to one than that water flooding. While the residual oil saturation ratios of surfactant-polymer flooding were farther to one than that of water flooding. This means that the amount of oil swept became more unequal between the two layers. It indicated that polymer flooding has good vertical sweep efficiency, while surfactant-polymer flooding has worse vertical sweep efficiency than water flooding.

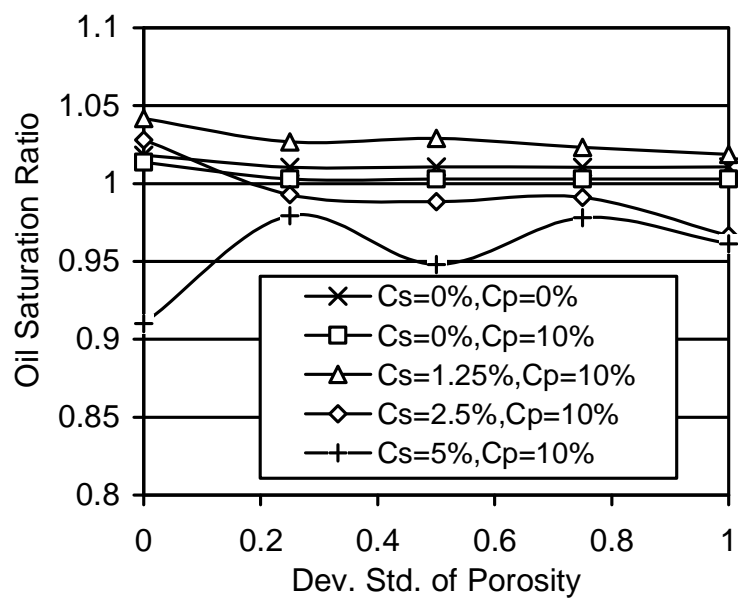

Fig. 1: Residual oil saturation ratio between the first and the second layers. 
Figure 2 shows residual oil saturation after injecting 1.25 PV of surfactant-polymer solution and chase water. Fig. 2 indicates that there was no significant change on the residual oil saturation as deviation standard of porosity increased. The fluctuation of the residual oil saturation was affected by the restriction on lateral direction due to more variation of pore size as the porosity deviation standard increased. The restriction in lateral direction made the injecting fluid to cross between the layers to find the most favorable path. Another result presented in Fig. 2 indicates that the residual oil saturation reduced as higher surfactant concentration applied. The average residual oil saturation for surfactant concentrations of $0 \%, 1.25 \%, 2.5 \%$, and $5 \%$ was $0.362 \pm 0.005,0.298 \pm 0.015$, and 0.204 \pm 0.026 , and $0.079 \pm 0.010$, respectively.

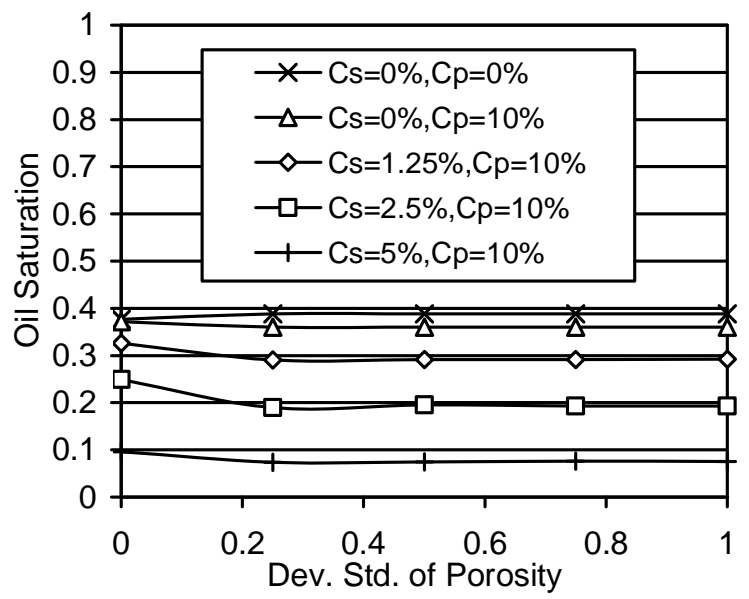

Fig. 2: Average residual oil saturation after injecting 1.25 PV.

The surfactant injected was a surface-active agent which had hydrophilic and hydrophobic parts. The parts solubilized oil and water to form emulsion. Fig. 3 shows the correlation between standard deviation of porosity and microemulsion saturation. As expected, higher microemulsion saturation was formed as higher surfactant concentration was used. The microemulsion saturation affected the residual oil saturation since the microemulsion phase contained water, surfactant and oil. Therefore the effect of surfactant concentration and standard deviation of porosity on the microemulsion saturation had reverse pattern to the residual oil saturation (Fig. 2 and 3). In the presence of water saturation, higher microemulsion saturation occupied the layer with lower oil saturation and vice versa. The average microemulsion saturations for surfactant concentration of $1.25 \%, 2.5 \%$, and $5 \%$ were $0.317 \pm 0.032,0.416 \pm 0.014$, and $0.547 \pm 0.004$, respectively.

Figure 4 shows oil recovery for various deviation standards of porosity and surfactant concentrations. The figure indicates that the oil recovery by surfactant-polymer flooding $\left(\mathrm{C}_{\mathrm{s}}>0 \%\right)$ was more sensitive than water flooding to the spatial distribution of multiple porosity fields. The recovery of oil tends to slightly fluctuate as the porosity deviation standard increases. The maximum alteration of oil recovery compared with the homogeneous porous media for surfactant concentrations of $0 \%, 1.25 \%, 2.5 \%$, and $5 \%$ was $3.6 \%, 9.2 \%, 5.3 \%$, and $5.5 \%$, respectively. Oil recovery was directly correlated with 
the microemulsion saturation and the residual oil saturation. Meanwhile, the saturations were affected by flow path which was resulted in the heterogeneity of porous media.

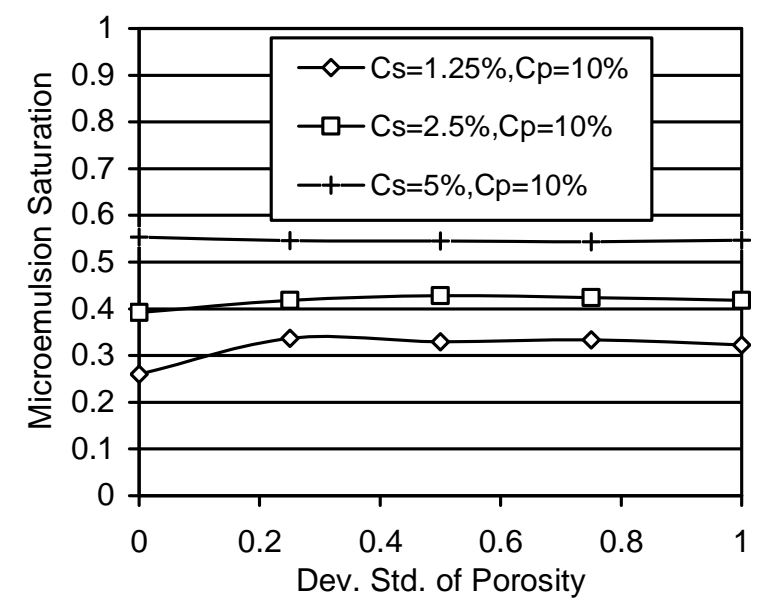

Fig. 3: Microemulsion saturation after injecting 1.25 PV.

Additional results presented in Fig. 4 indicate that, the oil recovery increases as the surfactant concentration increases. The average oil recovery for surfactant concentrations of $0 \%, 1.25 \%, 2.5 \%$, and $5 \%$ was $0.482 \pm 0.008,0.567 \pm 0.022,0.650 \pm 0.013$, and 0.714 \pm 0.017 , respectively. This phenomenon indicated that surfactant-polymer flooding improved sweep efficiency in lateral direction. Figures 2 to 4 show that although oil saturation in porous media was suppressed by applying higher surfactant concentration, but more oil left in the porous media in form of emulsion at 1.25 pore volume injection. Therefore, more water injection or a polymer slug drive was required to sweep out more emulsion.

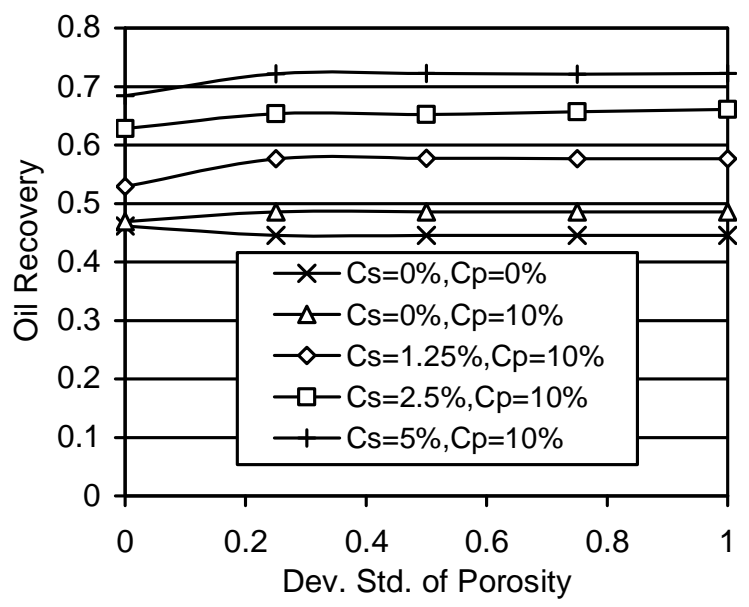

Fig. 4: Average oil recovery after injecting 1.25 PV. 


\section{CONCLUSION}

Based on the simulation results and analyses shown above, the following conclusions are made:

1. The effect of spatial heterogeneity of multiple porosity fields on surfactant-polymer flooding was higher than that on water flooding and polymer flooding.

2. Surfactant-polymer flooding results in more unbalance residual saturation in the two layers than water flooding and polymer flooding. This indicated that the vertical sweep efficiency of surfactant-polymer flooding was worse than water flooding and polymer flooding.

3. Although the effect of spatial heterogeneity of multiple porosity fields on the oil recovery of surfactant-polymer flooding was higher than that on water flooding and polymer flooding, the surfactant improved the oil recovery of polymer flooding and water flooding by increasing lateral sweep efficiency. The variation of recovery factor of surfactant-polymer flooding due to the reservoir heterogeneity was under $9.2 \%$.

\section{REFERENCES}

[1] A. Seethepalli, B. Adibhatla, K. K. Mohanty, "Wettability Alteration during Surfactant Flooding of Carbonate Reservoirs". SPE 89423, the SPE/DOE Fourteenth Symposium on Improved Oil Recovery, pp. 1-10, 2004.

[2] D. Zhang, Surfactant-Enhanced Oil Recovery Process for a fractured, Oil-Wet Carbonate Reservoir, Ph.D. Thesis, Rice University, Houston, U.S.A., 2005.

[3] N.F. Najafabadi, Modeling Chemical EOR Processes Using IMPEC and Fully Implicit Reservoir Simulators, Ph.D. Thesis, The University of Texas at Austin, 2009.

[4] W. Littmann, Polymer Flooding, Elsevier Science Publishing Company Inc., New York, 1988.

[5] S. Naji, Field Scale Simulation of Chemical Flooding, Ph.D. Thesis, The University of Texas at Austin, 1989.

[6] G. Brook, , Investigation of Non-Thermal Enhanced Oil Recovery Techniques for Heavy Oil Production, Master Thesis, University of Calgary, 1999.

[7] C. Zheng, B. L. Gall, T. R. French, R.S. Bryant, "Modeling and Simulation of PolymerEnhanced Oil Production," Systems and Information Technology Review Journal, Vol. 6, 2, pp. 55-67, 1998.

[8] H. Dakhlia, A Simulation of Polymer Flooding and Surfactant Flooding Using Horizontal Wells, Ph.D. Thesis, the University of Texas at Austin, 1995.

[9] Y. Shiyi, Y. Hua, S. Kuiyou, Y. Puhua, "Effects of Important Factors on Alkali/Surfactant/Polymer Flooding", SPE 50916, the 1998 SPE International Conference and Exhibition, pp. 357-374, 1998.

[10] R. Zhang, A. L. Wood, C. G. Enfield, S. W. Jeong, "Stochastical Analysis of SurfactantEnhanced Remediation of Denser-than-Water Nonaqueous Phase Liquid (DNAPL)Contaminated Soils," J. Environ. Qual., Vol. 32, pp. 957-965, 2003. 
[11] G. A. Pope and R. C. Nelson, "A Chemical Flooding Compositional Simulator," SPE Journal 6725, Vol. 18, 5, pp. 339-354, 1978.

[12] T. Elkateb, R. Chalaturnyk, P. K. Robertson, "Simplified Geostatistical Analysis of Earthquake induced ground response at the Wildlife Site, California, U.S.A," Can. Geothech. J., Vol. 40, pp. 16-35, 2003.

[13] I. Sahni, Wavelet Analysis of Multiple History-Matched Reservoir Models, A Report, Stanford University, 2003.

[14] G. Matheron, Les Variables Regionaliseés et Leur Estimation, Masson, Paris, 1965.

[15] S. H. Derakhshan, A Decision Support System for Variogram Calculation, MS Thesis, University of Alberta, 2007. 